\title{
Potensi korosivitas pada tanah endapan dataran banjir sungai Citarum di Karawang, Jawa Barat
}

\author{
Yanwar Yusup Rukmana ${ }^{1,2^{*}}$, Muhamad Ridwan ${ }^{2}$, Zufialdi Zakaria ${ }^{1}$, Dicky Muslim ${ }^{1}$, \\ Nadhirah Seraphine ${ }^{3}$ \\ ${ }^{1}$ Fakultas Teknik Geologi, Universitas Padjadjaran, Bandung \\ ${ }^{2} \mathrm{PT}$. Geosindo Utama, Bandung \\ ${ }^{3}$ Department of Science, Uppsala University, Swedia \\ Koresponden E-mail: yanwaryr@gmail.com
}

(Diterima 05 Februari 2020|Disetujui 7 Juni 2020|Diterbitkan 30 Juli 2020)

\begin{abstract}
Corrosion is the biggest problem for equipment that utilised metal, including infrastructure. Corrosion is degradation of metal quality due to the chemical reaction of a metal with the surrounding environment, including soil. Important indicators that contribute to the classification of the rate of corrosivity in soils are water content, $p H$, types of minerals, soil resistivity values and other chemical-physical parameters. The research area is in Anggadita Village, Klari District, Karawang Regency, West Java Province. Drilling and sampling locations are approximately 300 meters from the Citarum river. The article aimed to investigate between physical and chemical characteristics (soil texture, type of resistivity, $p H)$ of weathered sediments of the Citarum river flood plain to the classification of soil corrosivity. Soil classification in the study area is fine grained and classified into silt with high plasticity (MH-ML) and clay with high plasticity $(\mathrm{CH})$. The results of the analysis of the distribution of potential soil corrosivity in the study area indicate that the level of soil corrosivity is at a high level of corrosive to very high corrosive
\end{abstract}

\section{Keywords: corrosivity, citarum, resistivity, soil characteristics, $p H$}

Korosi merupakan masalah terbesar bagi peralatan-peralatan yang mempergunakan logam, termasuk dalam infrastruktur (Rieger, 1992; Lestari, 2019). Korosi adalah degradasi atau penurunan mutu logam akibat reaksi kimia suatu logam dengan lingkungannya (Bradford, 2001; Bahri, 2007; \& Shidiq, 2013). Faktor lingkungan seperti: udara, air, dan tanah (Wahyuni et al., 2014). Beberapa indikator penting yang berperan terhadap klasifikasi laju korosivitas pada tanah yaitu: kandungan air, $\mathrm{pH}$, jenis mineral, nilai tahanan jenis tanah dan parameter kimia-fisika lainnya (Warnana, 2015 \& Putra, et al., 2018).

Penelitian ini bertujuan untuk mempelajari hubungan/kaitan antara karakteristik fisik dan kimia tanah (ukuran besar butir/tekstur, tahanan jenis, $\mathrm{pH}$ ) lapukan endapan dataran banjir sungai Citarum terhadap klasifikasi korosivitas. Dengan adanya pemetaan korosivitas tanah yang baik diharapkan dapat mengidentifikasikan lebih lanjut area-area potensial yang berisiko mengalami korosivitas tinggi (HSE, 2011).

Indikator utama yang sangat signifikan dalam menentukan klasifikasi korosivitas tanah adalah nilai tahanan jenis tanah. karena laju dari korosivitas merupakan fungsi dari konduktivitas listrik (Okiongbo et al., 2013). Persentase ukuran butir (tekstur) pada tanah mempengaruhi variasi nilai tahanan jenis tanah. Semakin tinggi persentase butiran halus pada tanah, semakin tinggi kadar air (Farahnaz et al., 2018). Semakin tinggi kandungan air dalam tanah maka sifat konduktivitas tanah akan semakin tinggi dan nilai tahanan jenisnya akan semakin rendah (Irianto et al., 2014). Nilai tahanan jenis tanah rendah (konduktivitas tinggi) maka korosivitas tinggi. Sebaliknya, ketika nilai tahanan jenis tanah tinggi (konduktivitas rendah) maka korosivitas rendah (Warnana et al., 2015).

Korosivitas pada tanah dapat menyebabkan kegagalan pada infrastruktur. Korosi tanah sebagai salah satu faktor yang berkontribusi terhadap kegagalan jaringan pipa yang terkubur. Kegagalan Infrastruktur pada tanah saling berkaitan dengan beberapa faktor lain seperti: Shrink/swell clay, Erodibilitas tanah, Pengaruh akar pohon secara langsung dan tidak langsung (Pritchard et al., 2013). Korosi dipengaruhi kadar air, resistivitas tanah, $\mathrm{pH}$, oksigen terlarut, suhu dan aktivitas mikroba (Wasim et al., 2018). Korosi meningkat dengan meningkatnya kadar air tanah (Noor \& Al-Moubaraki, 2014).

Secara umum, korosi tanah merupakan mekanisme yang merusak karena reaksi yang terjadi antara material dengan lingkungan sehingga dapat menurunkan ketahanan pada pipa/logam (Noor \& Othman, 2010).

\section{BAHAN DAN METODE}

Secara garis besar penelitian dilakukan atas: (1) Studi Literatur yaitu mengumpulkan data penelitian terdahulu seperti tulisan-tulisan dan Peta yang akan dijadikan sebagai informasi awal sebelum melakukan penelitian. (2) Pekerjaan lapangan yaitu pengeboran geoteknik menggunakan mesin bor ShiTan XY-1 Core Drill Rig 30 dengan maksimal kedalaman 30 meter dan pengambilan contoh tanah tidak terganggu (Undisturb Sample) (Gambar 1). Sampel yang diambil dan dilakukan pengujian tahanan jenis tanah sebanyak 6 tabung, dengan variasi kedalaman mulai dari 1,5 meter sampai dengan 9,5 meter. (3) Contoh tanah tersebut 
selanjutnya dianalisis di laboratorium untuk mengetahui parameter fisika dan kimia tanah. Beberapa pengujian tersebut adalah: kadar air (ASTM D2216), batas atterberg (ASTM D4318), analisis ukuran besar butir tanah (ASTM D7928, D6913), nilai tahanan jenis tanah (ASTM G187-12), dan geokimia tanah (pH, Sulfat, Klorida, kandungan organik tanah) (ASTM D 4972, ASTM C 1114). (4) Pengolahan dan analisis data dilakukan sebagai tahapan terakhir dalam penelitian.

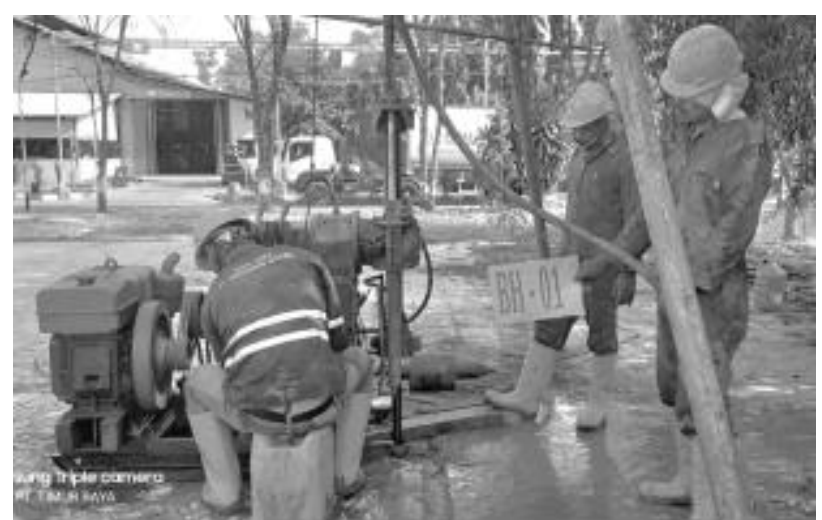

Gambar 1. Pengeboran Geoteknik dan Pengambilan UDS (Undisturbed Sample) Tanah. Sumber: Dok. PT. Geosindo Utama

Daerah penelitian secara administratif berada di Desa Anggadita, Kecamatan Klari, Kabupaten
Karawang, Provinsi Jawa Barat.Secara geografis berada pada koordinat $6^{\circ} 21^{\prime} 12.68^{\prime \prime} \mathrm{LS}-6^{\circ} 21^{\prime} 14.31^{\prime \prime} \mathrm{LS}$ dan 107¹9'53.16" BT - 107'19'55.24"BT. Berada diantara dua kota besar yaitu Bandung dan Jakarta sehingga menjadikan Karawang sebagai salah satu daerah strategis sebagai sentra industri (Chofyyan, 2015).

Lokasi pengeboran dan pengambilan sampel berjarak \pm 300 meter dari Sungai Citarum (Gambar 2). Material Sungai Citarum beragam, mulai dari bongkahan hingga perselingan antara pasir dan lempung. Erosi Sungai Citarum tidak hanya mengarah secara vertikal. Akan tetapi, mengarah juga secara lateral. Hal ini terbukti dengan bentukan sungai yang semakin melebar dan berkelok-kelok (Moechtar, 2011).

Berdasarkan peta geologi regional lembar Karawang (Achdan \& Sudana, 1992) litologi daerah penelitian termasuk kedalam endapan permukaan (Qaf). Qaf merupakan endapan dataran banjir yang tersusun atas Pasir lempungan, Lempung pasiran, Lempung humusan/gambutan yang berumur Kuarter (Gambar 3).

Secara umum, daerah penelitian merupakan dataran yang ditutupi oleh tanah sebagai hasil dari pelapukan endapan dataran banjir sungai citarum. Daerah penelitian masuk kedalam kawasan salah satu perusahaan produsen bahan kimia di daerah Karawang (Ridwan et al., 2019).



Gambar 1. Lokasi Pengambilan Data 


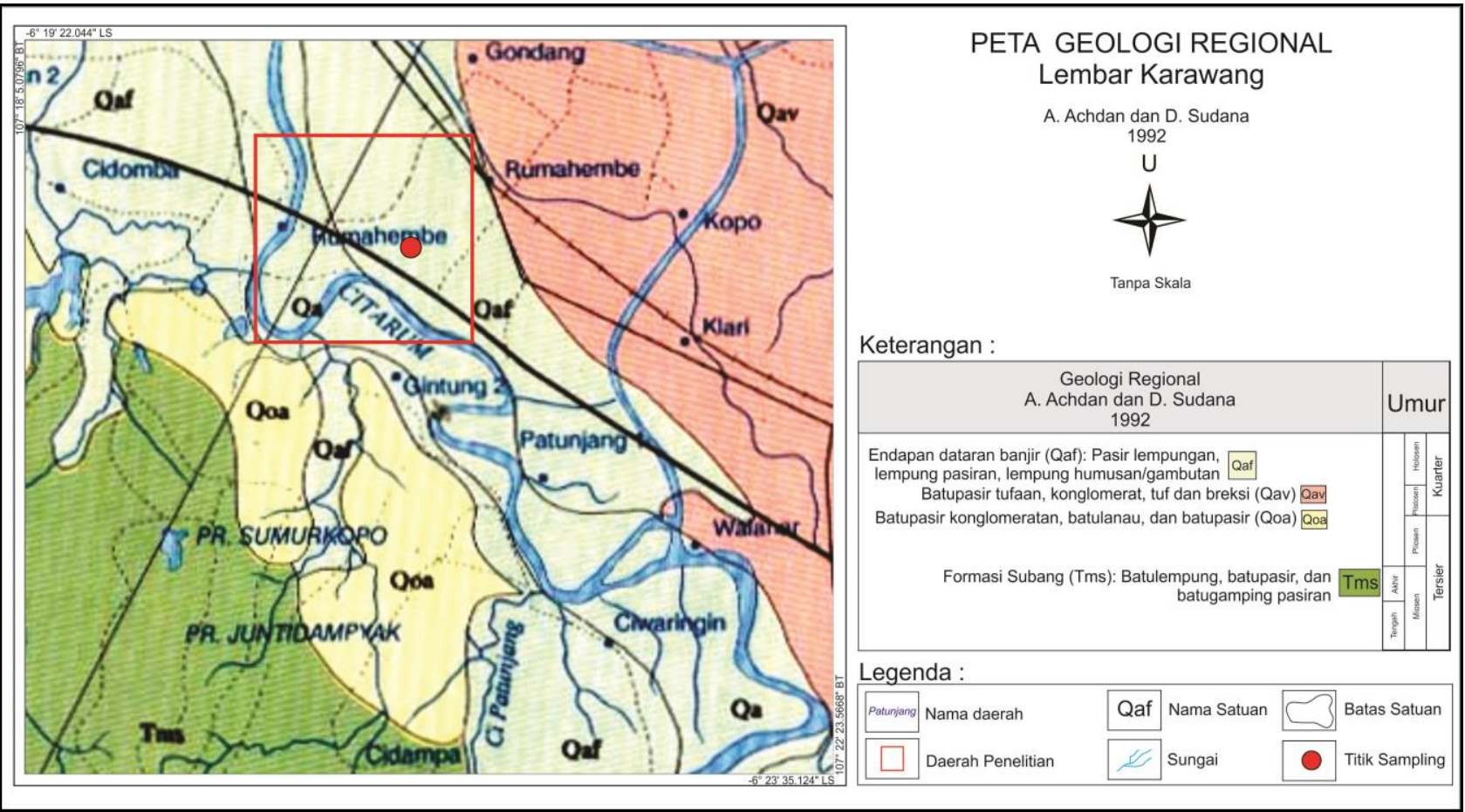

Gambar 3. Geologi Regional Daerah Penelitian (Modifikasi dari Achdan \& Sudana, 1992)

Endapan alur Sungai Citarum tersusun oleh kerikil-Pasir-Lempung. Material endapan berasal dari muatan dasar sungai ataupun material bawaan dari sumber di hulu. Ciri khas dari fasies ini yaitu relatif homogen mulai dari atas hingga bawah lapisan (Moechtar, 2011). Di atas endapan ini kemudian mengalami proses pelapukan sehingga mengandung beberapa oksida besi dan silika. Pada beberapa tempat sering juga terdapat sisa-sisa akar tanaman. Selanjutnya diikuti oleh proses pembentukan soil. Hal ini bisa menjadi salah satu penyebab derajat keasaman pada tanah meningkat.

Menurut Ridwan et al., (2019) di dalam laporan hasil penyelidikan tanah daerah karawang menyebutkan, rentang nilai $\mathrm{pH}$ tanah berkisar antara $5,10-5,15$. Perbedaan nilai $\mathrm{pH}$ pada tanah dipengaruhi oleh banyak faktor seperti: kandungan C-Organik (Thomas and Hargrove, 1984), karakteristik tanah dan Air, pengendapan material, vegetasi dan kedalaman tanah (Hanafiah, 2007).

\section{Pengujian Sampel}

Sampel tanah hasil dari lapangan selanjutnya diuji di laboratorium. Beberapa pengujian yang dilakukan seperti pada tabel 1 .

Tabel 1. Jenis Pengujian di Laboratorium

\begin{tabular}{ll}
\hline Jenis Pengujian & Metode Uji \\
\hline Kadar air & ASTM-D2216 \\
Analisis Ukuran Besar Butir & ASTM-D6913,D7928 \\
Tahanan Jenis & ASTM-G187-12 \\
ATT & ASTM-D4318 \\
pH & ASTM-C114-05 \\
\hline
\end{tabular}

Untuk proses pengujian tahanan jenis tanah dilakukan dengan metode soil box (Gambar 4) yang mengacu pada ASTM G187-12. Skema pengukuran tahanan jenis ini adalah Arus listrik DC (I) dialirkan kedalam sampel yang berada pada soil box yang memiliki panjang (L) dan luas permukaan (A) sehingga terjadi beda potensial (V). Parameterparameter tadi dimasukkan kedalam persamaan dibawah sehingga nilai tahanan jenis tanah bisa didapatkan dari setiap sampel.

$$
\mathrm{R}=\rho \frac{\mathrm{L}}{\mathrm{A}}
$$

\section{Dengan:}

R :Tahanan Jenis Listrik $(\Omega)$

$\rho \quad$ :Tahanan Jenis Tanah $(\Omega \mathrm{m})$

L : :Jarak Dua Elektroda $(\mathrm{cm})$

A :Luas Permukaan Sampel yang Dialiri Listrik $\left(\mathrm{cm}^{2}\right)$

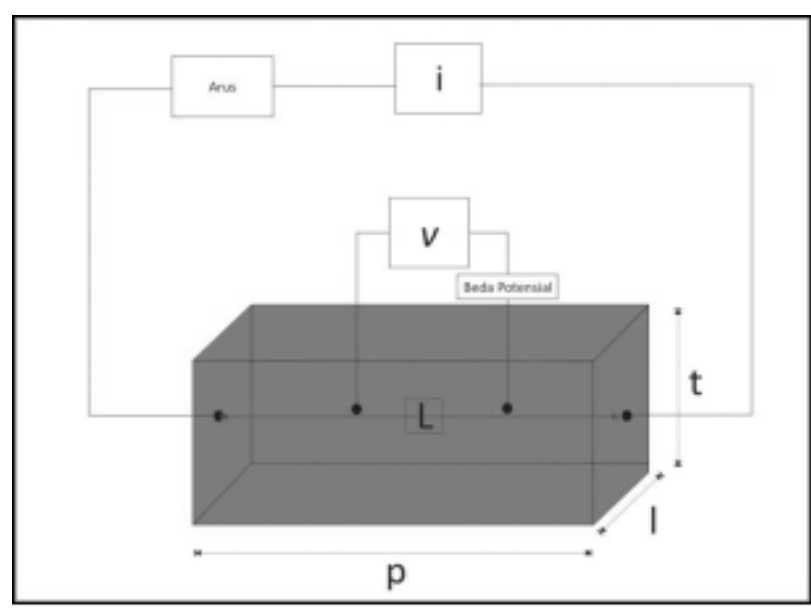

Gambar 4. Pengukuran tahanan jenis tanah 
Derajat pelapukan batuan mempengaruhi variasi nilai tahanan jenis tanah untuk setiap material (Reynolds, 1998). Oleh karena itu setiap material memiliki nilai tahanan jenis yang beragam (Tabel 2). Akan tetapi, rentang nilai tahanan jenis pada setiap material yang sama sering kali memiliki rentang nilai yang cukup jauh. Sehingga cukup sulit untuk mengidentifikasi secara detail.

Tabel 2. Nilai Tahanan jenis beberapa material geologi (Okiongbo et al., 2013).

\begin{tabular}{clc}
\hline No. & Jenis Tanah/material & Tahanan jenis $(\Omega m)$ \\
\hline 1 & Clay & $1-100$ \\
2 & Silts & $10-150$ \\
3 & Alluvium & $10-800$ \\
4 & Sandstone & $8-4000$ \\
5 & Shale & $20-2000$ \\
6 & Granite & $5000-5 \times 10^{6}$ \\
7 & Basalt & $1000-10^{6}$ \\
8 & Groundwater (fresh) & $10-100$ \\
9 & Sea water & 0.2 \\
\hline
\end{tabular}

Sumber: US Army, 1995

\section{Korosivitas Tanah}

Proses korosi secara elektro-kimia pada besi (Gambar 5) terdiri dari 4 komponen utama (Sidiq, 2013). (1) Anode (Anoda) (2) Cathode (Katoda) (3) Elektrolit : Bisa berupa tanah dan (4) Terhubungnya Anoda dan Katoda.

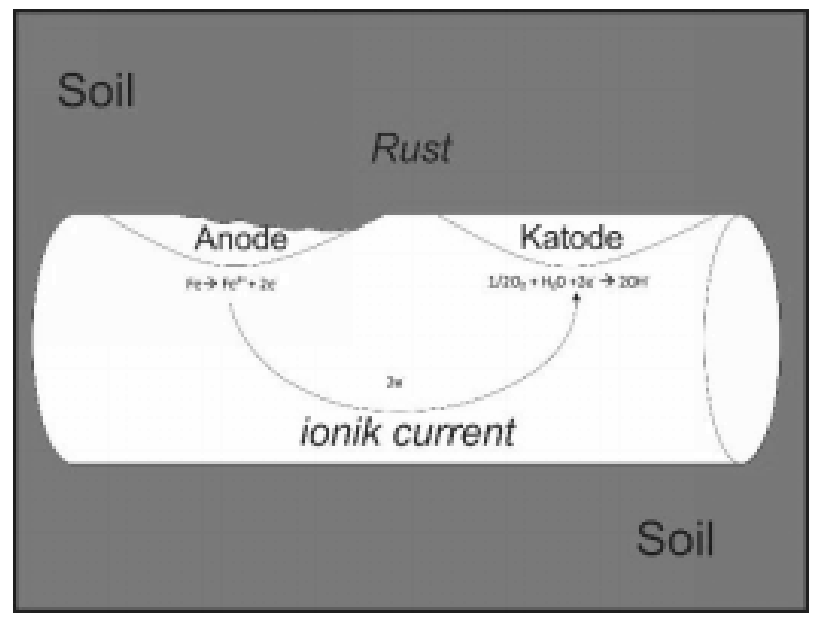

Gambar 5. Korosi pada besi (modifikasi dari Camitz, 1998)

Selain 4 komponen diatas, parameter lain yang ikut berpengaruh terhadap laju korosivitas Anonimous (2014) didalam tulisannya mengatakan, parameter lain yang ikut berperan terhadap laju korosivitas adalah: Air : berperan sebagai cairan elektrolit. kandungan air dalam tanah tergantung pada besar butir dan distribusi butir, tekstur, struktur, dan material organik. Derajat Aerasi : berperan dalam reaksi katodik. Pada tanah bertekstur kasar transportasi oksigen lebih cepat. Konsentrasi oksigen menurun dengan makin dalamnya tanah. $\mathrm{pH}$ : berperan sebagai solubilitas produk korosi dan juga aktivitas alami mikrobiologi. Klasifikasi korosivitas berdasarkan derajat keasaman $(\mathrm{pH})$ dibuat diperlihatkan dalam tabel 3. Tahanan jenis tanah : Berhubungan sebagai ionic current ketika terjadi reaksi oksidasi. Tanah dengan tahanan jenis tinggi akan memperlambat reaksi korosi. Klasifikasi korosivitas berdasarkan nilai tahanan jenis dibuat berdasarkan tabel 4. Redox potensial: Menjadi indikasi level oksigen yang tinggi. Sulfat: Biasanya beton mengalami korosi akibat kandungan sulfat yang tinggi. Khlorida : Ion ini menjadi berbahaya karena berperan langsung dalam reaksi anodik pada logam.

Tabel 3. Derajat keasaman dan klasifikasi korositas (Mulyono, 2017)

\begin{tabular}{lcc}
\hline Derajat Keasaman & $p H$ & $\begin{array}{c}\text { klasifikasi } \\
\text { Korosivitas }\end{array}$ \\
\hline Ekstrim & $<4,5$ & Sangat Korosif \\
Sangat Kuat & $4,5-5,0$ & Korosif \\
Kuat & $5,0-5,5$ & \\
Medium & $5,5-6,0$ & Neutral \\
Ringan & $6,0-6,5$ & \\
Netral & $6,5-7,3$ & \\
Basa Ringan & $7,3-7,8$ & Tidak Korosif \\
Basa Medium & $7,8-8,4$ & \\
Basa Kuat & $8,4-9,0$ & Korosif \\
Basa Sangat Kuat & $>9$ & Interkristal \\
\hline
\end{tabular}

Tabel 4. Nilai tahanan jenis dan klasifikasi korosivitas (Pritchard et al 2013)

\begin{tabular}{clc}
\hline No & Tahanan Jenis $(\Omega m)$ & $\begin{array}{c}\text { Klasifikasi } \\
\text { Korosivitas }\end{array}$ \\
\hline 1 & $<10$ & Sangat Tinggi \\
2 & $10,01-20,00$ & Tinggi \\
3 & $20,01-50,00$ & Sedang \\
4 & $50,01-100,00$ & Rendah \\
5 & $>100,00$ & Sangat Rendah \\
\hline
\end{tabular}

Sumber: ASTM,

Klasifikasi tanah dilakukan berdasarkan USCS (Unified Soil Classification System) yang dilakukan oleh Cassagrande di dalam Bowles (1989). Klasifikasi tanah berdasarkan kelompok jenis tanah dominan (berdasarkan ukuran besar butir) dan sub kelompok (berdasarkan gradasi, simbol plastis atau simbol komponen minor).

Tabel 5. Klasifikasi jenis tanah berdasarkan USCS

\begin{tabular}{|c|c|c|}
\hline & Simbol & Keterangan \\
\hline Jenis & G & Gravel \\
\hline \multirow[t]{3}{*}{ tanah } & S & Sand (pasir) \\
\hline & M & Silt (Lanau) \\
\hline & $\mathrm{C}$ & Clay (Lempung) \\
\hline \multirow{3}{*}{$\begin{array}{c}\text { Jenis } \\
\text { Gradasi }\end{array}$} & $\mathrm{W}$ & Well Graded \\
\hline & & (bergradasi baik) \\
\hline & $\mathrm{P}$ & $\begin{array}{c}\text { Poorly Graded } \\
\text { (bergradasi buruk) }\end{array}$ \\
\hline \multirow[t]{2}{*}{ Plastisitas } & $\mathrm{H}$ & $\begin{array}{l}\text { High Plasticity } \\
\text { (Plastisitas baik) }\end{array}$ \\
\hline & $\mathrm{L}$ & $\begin{array}{c}\text { Low Plasticity } \\
\text { (Plastisitas buruk) }\end{array}$ \\
\hline
\end{tabular}

Kelompok jenis tanah dominan diambil berdasarkan klasifikasi dari ukuran besar butir tanah (tabel 6). Tanah dengan ukuran besar butir kasar akan tertahan $(>50 \%)$ pada saringan No.200 sedangkan 
tanah dengan ukuran besar butir halus akan lolos $(>50 \%)$ melewati saringan No.200.

Tabel 6. Klasifikasi ukuran besar butir tanah

\begin{tabular}{ll}
\hline Jenis & Ukuran \\
\hline Berangkal (boulder) & $>250 \mathrm{~mm}$ \\
Kerikil (gravel) & $5 \mathrm{~mm}-150 \mathrm{~mm}$ \\
Pasir (sand) & $0,0074-5 \mathrm{~mm}$ \\
Lanau (silt) & $0,002 \mathrm{~mm}-0,0074 \mathrm{~mm}$ \\
Lempung (clay) & $<0,002 \mathrm{~mm}$ \\
\hline
\end{tabular}

\section{HASIL DAN PEMBAHASAN}

Litologi daerah penelitian didominasi oleh tanah dengan ukuran butir halus sebagai hasil pelapukan dari material endapan alur Sungai Citarum yang tersusun oleh Kerikil Pasir Lempung.

Berdasarkan pengamatan langsung di lapangan dan hasil pengujian terhadap 6 sampel yang diambil (Tabel 7), tanah di daerah penelitian memiliki persentase kadar air berkisar antara 46,04\% - 56,61\%. Nilai indeks plastisitas berkisar antara 19,40\% $41,83 \%$. Klasifikasi jenis tanah yang mengacu kepada USCS, ke 6 sampel tanah tersebut berjenis Lanau dengan tingkat Plastisitas Tinggi $(\mathrm{MH})$ dan Lempung dengan tingkat Plastisitas Tinggi $(\mathrm{CH})$ (Tabel 8). Klasifikasi korosivitas tanah berada pada Tinggi Sangat tinggi. Tingkatan korosivitas tanah ini diambil berdasarkan nilai derajat keasaman $(\mathrm{pH})$ dan nilai tahanan jenis tanah (Tabel 9).

Tabel 7. Skema pengujian sampel

\begin{tabular}{clcc}
\hline BH & Kedalaman (meter) & Uji resistivity & Uji karakteristik Fisik dan Kimia Tanah \\
\hline 01 & $(2,00-2,50)$ & $\checkmark$ & \\
& $(5,00-5,50)$ & $\checkmark$ & $\checkmark$ \\
& $(9,00-9,50)$ & $\checkmark$ & $\checkmark$ \\
02 & $(1,00-1,50)$ & $\checkmark$ & \\
& $(5,00-5,50)$ & $\checkmark$ & $\checkmark$ \\
& $(9,00-9,50)$ & $\checkmark$ & $\checkmark$ \\
\hline
\end{tabular}

Tabel 8. Hasil pengujian besar butir dan att tanah

\begin{tabular}{ccccc}
\hline BH & Kedalaman (meter) & Pemerian Tanah (USCS) & Butiran Kasar (\%) & Butiran Halus (\%) \\
\hline 01 & $(5,00-5,50)$ & $\mathrm{CH}$ & 6,46 & 93,54 \\
& $(9,00-9,50)$ & $\mathrm{MH}$ & 6,32 & 93,68 \\
02 & $(5,00-5,50)$ & $\mathrm{CH}$ & 0,64 & 99,36 \\
& $(9,00-9,50)$ & $\mathrm{CH}$ & 0,58 & 99,42 \\
\hline
\end{tabular}

Tabel 9. Klasifikasi korosivitas tanah berdasarkan nilai tahanan jenis dan $\mathrm{pH}$ tanah

\begin{tabular}{lllll}
\hline BH & Kedalaman $($ meter $)$ & $\rho(\Omega \mathrm{m})$ & $\mathrm{pH}$ & Klasifikasi Korosivitas \\
\hline 01 & $(2,00-2,50)$ & 10,72 & & Tinggi \\
& $(5,00-5,50)$ & 12,09 & 5,10 & Tinggi,Korosif \\
& $(9,00-9,50)$ & 12,53 & & Tinggi \\
02 & $(1,00-1,50)$ & 9,73 & & Sangat Tinggi \\
& $(5,00-5,50)$ & 10,31 & \multirow{2}{*}{5,35} & Tinggi,Korosif \\
& $(9,00-9,50)$ & 11,12 & & Tinggi \\
\hline
\end{tabular}

Hasil pengujian nilai tahanan jenis tanah pada 6 sampel terlihat bahwa nilai tahanan jenis tanah semakin tinggi seiring dengan bertambahnya kedalaman (Gambar 6). Hal ini diakibatkan karena seiring dengan bertambahnya kedalaman pengambilan sampel, persentase nilai kadar air pada tanah semakin berkurang (Gambar 7).

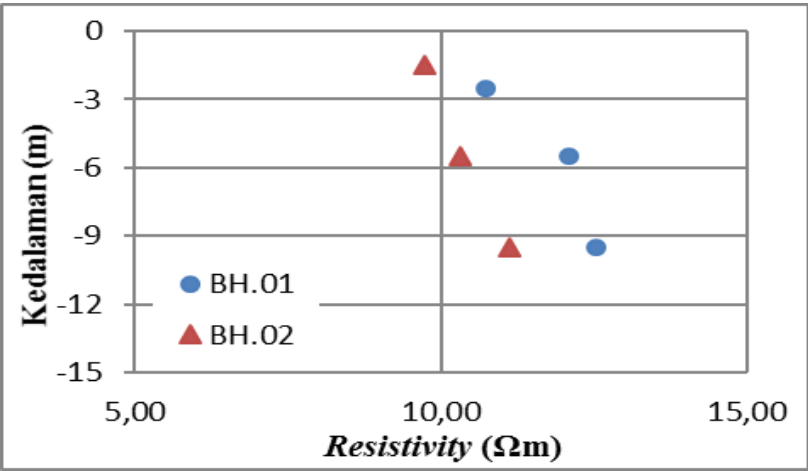

Gambar 6. Sebaran Nilai Tahanan Jenis Pada Setiap Kedalaman Pengambilan Sampel

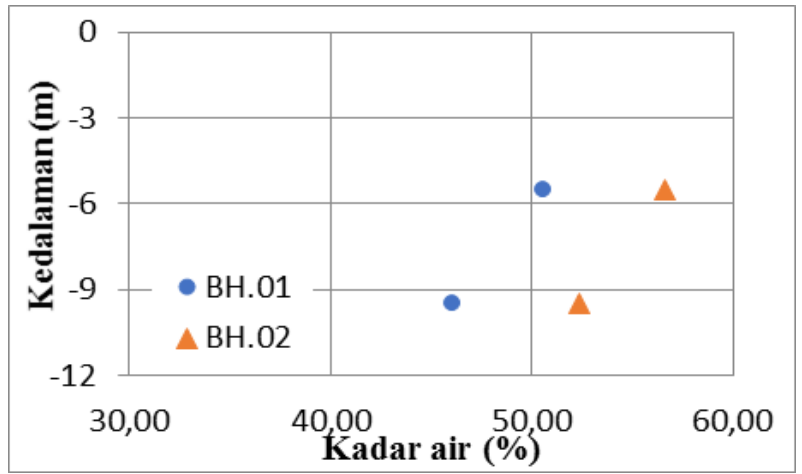

Gambar 7. Sebaran persentase nilai kadar air pada setiap Kedalaman Pengambilan Sampel

Nilai tahanan jenis tanah berperan sangat signifikan dalam menentukan klasifikasi dari laju korosivitas tanah (Okiongbo et al., 2013). Secara tidak langsung hal ini berpengaruh terhadap variabelvariabel penentu nilai tahanan jenis tanah itu sendiri seperti peranan dari persentase kandungan air dan persentase ukuran besar butir pada tanah. Oleh karena 
itu, untuk mengetahui sejauh mana hubungan dari variabel-variabel tersebut terhadap nilai tahanan jenis tanah dibuatlah grafik korelasi sederhana yang dapat menggambarkan hubungan antara 2 (dua) variabel tersebut.



Gambar 8. Grafik hubungan nilai tahanan jenis tanah dengan persentase kadar air

Grafik diatas menunjukkan koefisien korelasi yang bernilai negatif, dengan kata lain terlihat bahwa semakin tinggi persentase kadar air, semakin rendah nilai tahanan jenis tanahnya.

Dengan nilai fungsi $\mathrm{Y}=22,752-0.2187 \mathrm{X}$. dimana $\mathrm{R}^{2}=0,9306$ artinya hasil $\mathrm{Y}$ (resistivity) $93,06 \%$ dipengaruhi oleh faktor $\mathrm{X}$ (kadar air). Hubungan nilai korelasi (r) berdasarkan klasifikasi dari Sugiono (2010) adalah 0.965 dan termasuk kedalam korelasi sangat kuat.



Gambar 9. Grafik hubungan nilai tahanan jenis tanah dengan persentase butiran halus (Silt+Clay)

Grafik diatas menunjukkan koefisien korelasi yang bernilai negatif, dengan kata lain terlihat bahwa semakin tinggi persentase butiran halus, semakin rendah nilai tahanan jenis tanahnya.

Dengan nilai fungsi $\mathrm{Y}=37,923-0.2737 \mathrm{X} . \mathrm{R}^{2}=$ 0,8452 artinya hasil $\mathrm{Y}$ (resistivity) $84,52 \%$ dipengaruhi oleh faktor $\mathrm{X}$ (persentase silt+clay). Hubungan nilai korelasi (r) berdasarkan klasifikasi dari Sugiono (2010) adalah 0.919 dan termasuk kedalam korelasi sangat kuat.

Litologi endapan alur Sungai Citarum mulai dari kerikil-Pasir-lempung. Material endapan berasal dari muatan dasar sungai ataupun material bawaan dari sumber di hulu. Endapan ini kemudian mengalami proses pelapukan sehingga menjadi tanah dengan ukuran butir yang halus. Pada beberapa tempat sering terdapat sisa-sisa akar tanaman. Kandungan bahan organik didaerah penelitian berkisar antara 1,52 ppm - 7,9 ppm dan dapat menyebabkan peningkatan potensi korosivitas tanah. Hal ini terjadi akibat naiknya derajat keasaman pada tanah (Neff et al., 2006 ;\& Nurnburger., 2012).

Nilai tahanan jenis menjadi penting dalam menentukan klasifikasi korosivitas tanah (Okiongbo et al., 2013). Oleh karena itu perlu diketahui variabelvariabel apa saja yang berpengaruh terhadap variasi nilai tahanan jenis itu sendiri. Hubungan korelasi antara nilai tahanan jenis tanah dan nilai persentase kadar air bernilai sangat kuat (Gambar 8). Semakin tinggi kadar air dalam tanah maka nilai tahanan jenis tanahnya akan semakin rendah (Irianto et al., 2014).

Hubungan nilai tahanan jenis tanah dan persentase butiran halus (Silt + clay) menunjukkan korelasi sangat kuat (Gambar 9). Semakin tinggi persentase butiran halus pada tanah maka semakin rendah nilai tahanan jenis tanahnya. Tanah dengan derajat pelapukan tinggi memiliki ukuran besar butir yang relative lebih halus.

Potensi korosivitas tanah di daerah penelitian berdasarkan klasifikasi korosivitas tanah (Tabel 3 dan Tabel 4) berada pada tingkatan tinggi - sangat tinggi. Hal ini diakibatkan karena nilai tahanan jenis yang relative rendah. Semakin rendah nilai tahanan jenis tanah maka tanah semakin korosif. Derajat pelapukan pada batuan mempengaruhi variasi nilai tahanan jenis tanah yang berbeda-beda (Reynolds, 1998).

Variabel lain yang harus diperhitungkan untuk klasifikasi korosivitas tanah selain nilai tahanan jenis adalah karakteristik tanah termasuk juga derajat keasaman tanah (Putra, et al., 2018 \& Tiba, 2012). Derajat keasaman di daerah penelitian bersifat asam. Semakin asam tanah semakin tinggi tingkat korosivitasnya (Mulyono, 2017).

Penelitian tentang korosivitas tanah yang sangat sedikit (Saheb et al., 2010) menyebabkan variabelvariabel yang ikut berkontribusi dalam menentukan tinggi-rendahnya nilai tahanan jenis tanah seringkali terabaikan sehingga rentang nilai tahanan jenis tanah pada suatu lokasi sangat sulit untuk ditentukan (Busby et al., 2012).

\section{SIMPULAN}

Berdasarkan klasifikasi USCS (Unified Soil Classification System) tanah di daerah penelitian merupakan tanah berbutir halus berjenis Lanau dengan tingkat Plastisitas Tinggi (MH-ML) serta Lempung dengan tingkat Plastisitas Tinggi $(\mathrm{CH})$.

Hasil analisis dari ke 6 sampel, potensi korosivitas tanah di daerah penelitian menunjukkan bahwa tingkat korosivitas tanah berada pada tingkatan korosif tinggi sampai dengan sangat tinggi.

\section{UCAPAN TERIMA KASIH}

Penulis mengucapkan terimakasih kepada pimpinan perusahaan PT. Geosindo Utama yang telah memberikan ijin memakai data perusahaan. Juga 
kepada pembimbing yang telah meluangkan banyak waktu, kesabaran, juga memberikan arahan dalam menyelesaikan karya tulis ini.

\section{DAFTAR PUSTAKA}

Achdan, A., \& Sudana, D. (1992). Peta Gelogi Lembar Karawang. Bandung: Puslitbang Geologi.

Anonimous. (2012). Soil Corrosion. Diambil 28 Januari2020,dari:https://mechanicalbrothers.word press.com/2012/07/04/soil-corrosion/

ASTM. (2012). ASTM G187 - 12 Standard test method for measurement of soil resistivity using the two electrode soil box method. ASTM International, West Conshohocken, PA, 2003.

Bahri, S. (2007). Penghambatan korosi baja beton dalam larutan garam dan asam dengan menggunakan campuran senyawa butilamina dan oktilamina. GRADIEN: Jurnal Ilmiah MIPA,3(1),pp.231236.https://ejournal.unib.ac.id/i ndex.pHp/gradien/article/view/211/185

Bradford, S. A. (2001). Practical handbook of corrosion control in soils; Pieplines, tanks, casings, Cables, Publishing Ltd, Edmonton, Canada.

Bowles, J. E. (1989). Sifat-Sifat Fisis dan Geoteknis Tanah (Mekanika Tanah). Edisi Kedua, Penerbit Erlangga, Jakarta.

Busby J. P., Entwistle, D., Hobbs, P., Jackson, P. Johnson N, Lawley R, Kinley K, Mayr T, Palmer R., Raines, M., Reeves, H., Tucker, S., Zawadzka, J. (2012). A GIS for the planning of electric earthing. Journal of Engineering Geology and Hydrogeology. Vol. 45, pp. 379-390. https://doi.org/10.1144/1470-9236/11-023

Camitz, G. (1998). Corrosion and protection of steel piles and sheet piles in soil and water. Report 93, Swedish Commission on pile research. Availableat:http://www.geoforum.com/info/pilei nfo/corrosion.asp.

Chofyan, I., Rustan, H. U., \& Hariyanto, A. (2015). Upaya Mempertahankan Kabupaten Karawang Sebagai Lumbung Padi Nasional. Laporan Akhir Penelitian. Universitas Islam Bandung.

Farahnaz, N., SopHian, R. I., \& Agung Mulyo, H. (2018). Potensi Tanah Mengembang Hasil Lapukan Batuan Vulkanik Berdasarkan Indeks Plastisitas Di Kawasan Desa Cilayung. Geoscience Journal, 2(1), pp.82-

89.http://journal.unpad.ac.id/geoscience/article/d ownload/15600/7323

Hanafiah, K. A. (2007). Dasar-Dasar Ilmu Tanah. PT. Raja Grafindo Persada, Jakarta.

HSE. (2011). HSE/Ofgem: 10 year review of the iron mains replacement program. Prepared by Cambridge Economic Policy Associates Ltd for the Health and Safety Executive and Office of Gas and Electricity Markets.

Irianto, A. I., \& Rahmawati, E. (2014). Prototipe Alat Ukur Resistivitas Tanah Dengan Metode FourPoint Probes. Prosiding Pertemuan Ilmiah XXVIII HFI, Jateng \&DIY, ISSN:0853-0823.
Lestari, D. S., (2019). Perhitungan Nilai Korosivitas Air Terhadap Infrastruktur Sumber Daya Air Berbahan Logam. Jurnal Infrastruktur, Vol.5 hal.72.

Moechtar, H. (2011). Sedimentologi Dan Stratigrafi Endapan Sungai Citarum Di Wilayah Peralihan Morfologi Pegunungan Dan Dataran Tinggi Bandung Antara Desa Cikawao Dan Desa Nagrak (Kec. Pacet) Dan Desa Sukamaju (Kec. Majalaya), Kab. Bandung. Jurnal Geologi Dan Sumberdaya Mineral, 21(4), Pp.191-

201.http://dx.doi.org/10.33332/jgsm.geologi.21.4. 191-201

Mulyono, P. R. (2017). Perancangan Sistem Proteksi Katodik Anoda Tumbal Pada Pipa Baja API 5L GRADE B Dengan Variasi Jumlah Coating Yang Dipasang Di Dalam Tanah. Surabaya. Skripsi: Institut Teknologi Sepuluh Nopember.

Neff, D., Dillmann, P., Descostes, M., \& Beranger, G. (2006). Corrosion of iron archaeological 48 artefacts in soil: Estimation of the average corrosion rates involving analytical techniques and thermodynamic calculations". Corrosion Science. Vol. 48, pp. 2947-2970. https://doi.org/10.1016/j.corsci.2004.05.029

Noor, E. A., Al-Moubaraki, A. H. (2014). Influence of Soil Moisture Content on the Corrosion Behavior of X60 Steel in Different Soils. Arab J Sci Eng 39, pp. 5421-5435 https://doi.org/10.1007/s13369014-1135-2

Noor, N. M. d., \& Othman, S. R. (2010). Soil Corrosion and Integrity Management of Buried Pipeline, Jurutera, IEM Bulletin, Oct 2010, pp. 1012

Nurnburger, U. (2012). Long time behaviour of nongalvanized and galvanized steels for geotechnical stabilization applications. Materials and corrosion. Vol. 63, pp. 1173-1180.

https://doi.org/10.1002/maco.201206680

Okiongbo, K. S. \& Ogobiri, G. (2013). Predicting soil corrosivity along a pipeline route in the Niger Delta Basin using geoelectrical method: Implications for corrosion control". Engineering,5(03),p.237.http://dx.doi.org/10.4236 /eng.2013.53034

Pritchard, O., Hallett, S. H. \& Farewell, T. S. (2013), "Soil corrosivity in the UK-Impacts on Critical Infrastructure”. ITRC-Infrastructur Transition Research Consortium, Cranfield

University.https://itrc.ouce.ox.ac.uk/wpcontent/PDF s/Soil-corrosivity-impacts-UK-infrastructurereport.pdf

Putra, R., Muhammad., Huzni, S., \& Fonna, S. (2018). Pengaruh Faktor Lingkungan Terhadap Potensi Korosi Pada Pipa Air Bawah Tanah di Jalur Kreung Peusangan Hingga Krueng Geukueh, Aceh Utara. Jurnal Teknik Mesin Untira, IV/I

Reynolds, J. M. (1998). An Introduction to Applied and Environtmental GeopHysics. New York: John Wiley \& Sons. 
Ridwan, M., Sunandi., \& Rukmana, Y. Y. (2019). Laporan Soil Investigasi Pabrik PT. BIB Karawang. Laporan Pekerjaan. Bandung: PT. Geosindo Utama. Tidak Dipublikasikan.

Rieger, H. P. (1992). Electrochemistry, 2nd ed. Chapman and Hall Inc, New York, 412-421.

Saheb, M., Descostes, M., Neff, D., Matthiesen, H., Michelin, A., \& Dillmann P. (2010). Iron corrosion in an anoxic soil: Comparison between thermodynamic modeling and ferrous archaeological artefacts characterised along with the local in situ geochemical conditions. Applied geochemistry. Vol. 25, pp. 19371948.https://doi.org/10.1016/j.apgeochem.2010.1 0.010

Shidiq, M. F. (2013). Analisa korosi dan pengendaliannya. Jurnal foundry, 3(1), pp.2530.ISSN:20872259.http://www.academia.edu/do wnload/37414696/53-143-1-PB.pdf

Sugiyono. (2010). Metode Penelitian Kuantitatif, Kualitatif, \& RND. Bandung : Alfabeta.
Thomas, G. W., \& Hargrove, W. L. (1984). The chemistry of soil acidity. In Adams, F (Ed). Soil Acidity and Liming Second edition", Wisconsin (USA): American Society of Agronomy Inc. https://doi.org/10.2134/agronmonogr12.2ed.c1

Tiba, C., de Oliveira, E. M. (2012). Utilization of cathodic protection for transmission towers through pHotovoltaic generation. Renewable energy, Vol. 40, (1), pp. 150-156 .https://doi.org/10.1016/j.renene.2011.09.020

US Army Corps of Engineers. (1995). Geo Physical Explorationfor Engineering and Environmental Investigations. EM1110-1-1802.

Wahyuni, T., \& Ab, S. (2014). Pemanfaatan Tanin Ekstrak Daun Jambu Biji Terhadap Laju Korosi Besi Dalam Larutan $\mathrm{NaCl} 3 \%(\mathrm{w} / \mathrm{v})$. Jurnal Konversi,3(1).https://doi.org/10.24853/konversi.3 $.1 . \% 25 \mathrm{p}$

Warnana, D. D., Iswahyudi, A., \& Prabawa, S. E. (2015). Penentuan Area Korosi Tanah Lokal Berdasarkan Resistivitas Tanah Untuk Perancangan Sistem Proteksi Katodik". Jurnal Geosaintek, 01/01.

Wasim, M., Shoaib, S., Mubarak, N. M., Imanuddin, \& Asiri, A. M. (2018). Factors influencing corrosion of metal pipes in soils. Environ Chem Lett 16, pp.861-879 